\title{
Managing Muslims: imperial Japan, Islamic policy, and Axis connections during the Second World War*
}

\author{
Kelly A. Hammond
}

University of Arkansas, Department of History, 416 Old Main, Fayetteville, Arkansas 72701, USA

E-mail: kah018@uark.edu

\begin{abstract}
Probing into Japan's quest to legitimize itself within the Islamic sphere, this article examines some of the lessons that imperial Japan hoped to learn from the Germans and the Italians regarding their respective handling of Muslim populations in the Middle East and North Africa. For their part, Muslims living under Japanese occupation on the mainland often benefited from Axis cooperation and were able to create relationships with Muslims beyond China. In the article, I posit that Japanese militarists used their Axis connections as a powerful rhetorical tool to position themselves as liberators from Western imperialism and communism throughout Asia. I also argue that, by examining intellectual currents circulating Eurasia through Axis-facilitated connections, we glean a more nuanced understanding of global anti-colonial movements among Muslim populations from the Maghreb to Manila in the post-war era.
\end{abstract}

Keywords China, Islam, Japanese imperialism, Second World War, Sino-Muslims, transnationalism

\section{Introduction}

After the Second World War started on mainland China in July 1937, but before the German invasion of Poland in September 1939, cooperation between the Italians and the Japanese allowed five Muslims from Beijing to go on a Japanese-sponsored hajj pilgrimage to Mecca. Without visa sponsorship from the Italian consulate in Shanghai and passage on an Italian steamship, the Chinese pilgrims, who included the well-known Beijing Muslim Tang Yichen, would never have made it from Japanese-occupied China to Italian-occupied Eritrea. From Eritrea, they boarded another Italian vessel that ferried them across the Red Sea to Jeddah with East African pilgrims headed to Mecca. ${ }^{1}$ On a number of occasions, their journey was nearly cut short: intimidating Gurkha guards in Shanghai would not let them enter the British

I would like to thank Reto Hoffman and Daniel Hedinger for organizing the 'Axis Empires' workshop at the Center for Advanced Studies in Munich. A shorter version of this article was presented there. I would also like to thank all the participants at the workshop for their invaluable feedback and insights.

1 Tang Yichen, Maijia xunli ji (Hajj journal), Beiping: Zhenzong Publishing House, 1943. 
consulate; Chinese Nationalist-supported informants in Singapore demanded to see their travel documents and threatened to print information about these Japanese 'collaborators' (Chinese: hanjian) in Singapore's Chinese-language newspapers; and British customs agents in Hong Kong and Calcutta threatened to revoke their visas if they disembarked onto British-controlled land. However, the five men managed to make the arduous journey and complete their hajj in large part because of their status as travellers on an Italian steamship with Italian-sponsored visas. Supported in their religious journey by the would-be-Axis powers, in some ways these five men were pawns, deeply involved in the international diplomacy of the impending world war; in other ways, the hajjis from north China actively navigated and circumvented obstacles they faced with the help of the Japanese and the Italians. This type of cooperation between the Axis powers forged connections between Muslims around the globe and provided the Japanese with the means to expand their influence in occupied China, Southeast Asia, and the greater Islamic world.

From the late nineteenth century, emerging nationalisms and the threat of outside aggression problematized the identity and loyalty of minority populations in China, and Japanese imperialists worked to cultivate relationships with Muslims living in China's borderlands. ${ }^{2}$ Japanese agents were known throughout the espionage world of adventurer-seeking intrigue for their frequent conversion to Islam and for their ability to learn difficult Central Asian languages. These faculties allowed them to blend in and integrate themselves into local networks throughout Afghanistan, Iran, Siberia, Mongolia, and north-west China. Japanese spies worked to infiltrate the Turkic-speaking Uyghur populations in Xinjiang, given the Chinese Nationalists (GMD)'s precarious position in the region after the 1911 Republican Revolution. However, they were more successful in their collaboration with Hui Muslims in north China. Hui Muslims are the Chinese-speaking descendants of Arab and Persian traders who intermarried with Han Chinese women but retained their Islamic religious beliefs. Often referred to as Sino-Muslims, their communities were distinct and separate from the Han Chinese, the Uyghurs, and other Muslim minorities. ${ }^{3}$ They are both historically powerful and present intermediaries in the daily life of most large Chinese cities.

Recent scholarship on modern China focuses primarily on the Chinese Communist (CCP) successes incorporating minority populations into the national imagination. This approach overlooks the critical role of the Japanese empire in shaping policy aimed at Muslims, a community estimated to be around twenty million in interwar China. Currently, scholars trace a direct lineage of the CCP's contemporary ethnic minority policy back to communist ideology formulated in their increased encounters with ethnic minorities on the Long March (1934-35). However, this approach precludes the possibility of alternative visions of autonomy that emerged during an era of collaboration and internationalism partly enabled by Japanese imperialism. By contrast, I take into account the important transnational and global connections created and maintained by Japanese imperialists with Muslims who lived under the shadow of occupation. Muslims in China used Japanese connections with the Germans and the Italians to create relationships beyond occupied China. At the same time, the Sino-Muslim

2 National Archives Research Administration, College Park, Maryland, Office of Strategic Services (henceforth NARA, OSS), RG 226 2-4-3 890.2, 'Japanese attempts at infiltration among Muslims in Russia's borderlands', August 1944.

3 Jonathan Lipman, Familiar strangers: a history of Muslims in northwest China, Seattle, WA: University of Washington Press, 1998. 
community was under the watchful eye of Japanese Pan-Asianists, who were developing elaborate plans to make use of these transnational networks as part of their strategies for imperial expansion into Southeast Asia and beyond. These efforts were coupled with Japanese attempts to foment anti-colonial and anti-communist dissent among Muslim populations throughout Southeast Asia, Central Asia, and the Indian Ocean.

The enduring question of how properly to 'manage Muslims' under their control was something that the Germans, the Italians, and the Japanese all had in common. I argue that Japanese militarists used their connections with the Axis as a powerful rhetorical tool to position themselves as liberators throughout Asia. The particularities of each of the Axis powers' imperial pursuits often prevent us from looking for similarities between them. However, exploring how policy and ideas regarding Muslims circulated and were adapted in Axis-controlled areas provides an illuminating point of convergence between Germany, Italy, and Japan. Examining the treatment of Muslims under Axis control becomes a starting point for putting Japanese, German, and Italian imperialisms in conversation, rather than continuing to treat Axis imperial aspirations as disparate endeavours. ${ }^{4}$ Although their objectives sometimes differed, the Axis powers used similar tactics to varying degrees of success in their efforts to win the hearts and minds of Muslims, from the Maghreb to Manila. They also observed each other's actions and strategies both within Muslim communities and in Muslim-dominated regions very closely. Like the Japanese, the Germans and the Italians considered their Muslim policies to be an important priority throughout the war. Also, in a similar manner to the Germans and the Italians, the Japanese set up the Greater Japan Islam League (Dai Nippon Kaikyō Kyōkai), which enlisted academics to issue publications, translate works from Arabic and Persian, and produce a plethora of policy documents offering advice to military advisers for handling unfamiliar Muslims.

Using opposition to American and British imperialism coupled with anti-Soviet agitation, the Axis understood well the potential of destabilizing Allied claims to regions throughout Eurasia and North Africa where Muslims lived. The destruction of Allied - especially British and Soviet - influences in these regions 'would have immeasurably increased their chance for success' during the war. ${ }^{5}$ For their part, American and British observers found the Axis tactics of sympathizing with the anti-imperialist and anti-Soviet sentiments among local populations troubling, and American observers noted that many 'Islamic countries are ill-equipped to withstand' Axis propaganda and infiltration. ${ }^{6}$ There were also differences, of course, in the Axis policies geared at Muslims: whereas inflammatory anti-Zionist and anti-Jewish rhetoric was a mainstay in Nazi propaganda for the Middle East, the Japanese did not regularly rely on anti-Jewish propaganda as a tool to influence Muslim populations under their control. ${ }^{7}$

Although their tactics were similar, all three powers localized and adapted their propaganda and ideology aimed at Muslims in ways that suited their needs and situations. ${ }^{8}$ In the case of the Japanese, they expended a fair amount of energy trying to grapple with the ideological similarities between Pan-Asianism and Pan-Islamism. There are a number of important works that focus on the likenesses and differences between these two fin-de-siècle

4 Reto Hoffman, The fascist effect: Japan and Italy, 1915-1952, Ithaca, NY: Cornell University Press, 2015.

5 Seth Arsenian, 'Wartime propaganda in the Middle East', Middle East Journal, 2, 4, 1948, p. 417.

6 NARA, OSS, RG 226 190-3-4-3 890.1, 'Japanese infiltration among Muslims throughout the world', July 1944.

7 Jeffrey Herf, Nazi propaganda for the Arab World, New Haven, CT: Yale University Press, 2009.

8 Ibid., p. 3. 
transnational movements, and the ways in which these discourses connected Muslims from the Ottoman empire and the Japanese in new ways. In particular, the Turkish scholars Celim Aydin and Selçuk Esenbel have compared Ottoman (and later Turkish) and Japanese anti-Western sentiments, focusing on intellectual trends circulating among non-Western, anti-imperial movements throughout the late nineteenth and early twentieth centuries. $^{9}$

It is not my intention to question the merit of this scholarship, only to point out that these works focus primarily on Japanese-Turkish relations, leaving others who participated in these networks, such as the aforementioned hajjis from China, out of the equation. Both Pan-Islamism and Pan-Asianism as articulated by Ottoman and Japanese intellectuals were transnational ideologies; beyond being simply reactions to Western nationalism and imperialism, however, they presented disenfranchised people throughout Eurasia with aspirational ideals and a potential 'greenbelt against communism'. ${ }^{10}$ Japan provided a space for ideas about the commonalities between Muslims from around the world to flourish: in the bustling metropolis of Tokyo, Muslims met to learn, discuss, and debate the similar issues they were facing in their respective homelands. ${ }^{11}$ In their overtures to Muslims from occupied China, the Japanese provided men such as Tang Yichen and his compatriots with a space to operate between their local communities and burgeoning global Islamic movements. ${ }^{12}$ Thus the Axis powers supplied the opportunity - in Berlin, Rome, or Tokyo - for Muslim men and women who saw themselves as disenfranchised by Soviet and Chinese communism, British, Dutch, American, and French colonialism, or Han Chinese nationalism to share their grievances and contemplate their next moves.

\section{The Tokyo Mosque: a telling vignette}

On Thursday May 12, 1938, the Tokyo Mosque opened with great fanfare. The opening of the mosque coincided with the birthday of the Prophet Muhammad, a symbolic overture that was surely not lost on the prominent attendees from all over the Islamic world. At the time of construction, there were around six hundred Muslims resident in Japan, who were mostly exiled Indians and Crimean Tatars, along with a handful of Japanese converts. ${ }^{13}$ The opening ceremonies were presided over by the charismatic Imam Abürreşid Ibrahim, a Crimean Tatar exiled from Russia who had found a place for himself among the growing émigré community seeking refuge in Japan after the Bolshevik Revolution. ${ }^{14}$ Five Muslims from occupied China made the journey to Tokyo to take part in the opening ceremonies: Tang Yichen, the presiding head of the Japanese-sponsored Chinese Muslim General Assembly, who later the same year

9 For example, Cemil Aydin, The politics of anti-westernism in Asia: visions of world order in Pan-Islamic and Pan-Asian thought, New York, NY: Columbia University Press, 2007; Selçuk Esenbel, ed., The rising sun and the Turkish crescent: new perspectives on the history of Japanese Turkish relations, Istanbul: Boğaçizi Unversity Press, 2008.

10 Selçuk Esenbel, 'Japan's global claims to Asia and the world of Islam: transnational nationalism and world powers, 1900-1945', American Historical Review, 109, 4, 2004, p. 1143.

11 Ibid., pp. 1141-43.

12 Sebastian Conrad and Prasenjit Duara, 'Viewing Regionalisms from East Asia', Washington, DC: American Historical Association pamphlet series, 2013, pp. 12-36.

13 NARA, OSS, RG 226 190-3-4-3 890.1.

14 For more on Abdürreşid İbrahim's colorful life, see Noriko Yamazaki-Unno, 'Abdürreşid İbrahim's journey to China: Muslim communities in the late Qing as seen by a Russian-Tatar intellectual', Central Asian Review, 33, 3, 2014, pp. 405-20. 
led the Japanese-sponsored hajj delegation, was accompanied by Liu Jinbiao, Li Zongqing, Zhao Yunsheng, and Wang Lianyu. Among other important Muslim dignitaries present at the inaugural Friday prayers was Prince Hussein of Yemen, the third son of Imam Yahya, as well as the Afghan, Turkish, and Egyptian consuls, and representatives from the Kingdom of Saudi Arabia, the Dutch East Indies, India, and the Philippines. ${ }^{15}$

The relationship between Italy and Yemen explains why Prince Hussein was the guest of honour at the opening of the Tokyo Mosque. After the renewal of the Italian-Yemeni Treaty in 1937, Imam Yahya sent a letter to Mussolini which pointed to Italy's continued support for Yemeni 'independence'. He wrote:

This treaty is the new mirror that reflects the devout and amicable relationship between the two Kingdoms, as well as indicating the aims of friendly collaboration which the Italian Government has shown towards our Kingdom and it is a fine example, for Islamic countries and Muslim peoples, of upstanding conduct and a greater level of concern ... We are infinitely and deeply grateful for the political course the Italian Government has followed in relation to us and toward all Islamic countries and we wish for you that said policy may be advanced ever further. ${ }^{16}$

Although hindsight allows for a cynical reading of this passage, it does explain why the Italians were happy to help defray the cost of Prince Hussein's trip to Japan, sending the son of a trusted Muslim collaborator to represent both Yemen and Italy at the opening ceremonies less than a year later. When Prince Hussein gave his opening remarks to the guests, a number of commentators mentioned that he did so in both Arabic and Italian.

The opening of the mosque and Prince Hussein's visit were reported extensively in the Japanese, Arabic, and Italian press. ${ }^{17}$ When the prince decided to prolong his sojourn in Tokyo rather than return to Yemen with the rest of the Yemeni delegation, the Italian press hypothesized about the reasons why he had decided to stay on in Japan. Three months after the opening ceremonies for the Tokyo Mosque, Oriente Moderno speculated that Prince Hussein had extended his trip for two possible reasons: 'He may be interested in establishing an alliance between Muslims of the Far East and Arabia to combat communism and the Soviets. Others believe it is more probable that he is simply involved in the conclusion of a trade and friendship treaty between Yemen and Japan. ${ }^{, 18}$ Both of these reasons are probable, and it was more likely a combination of the two that kept Prince Hussein in Japan longer than he had originally anticipated. Here was the son of an Italian-Allied Arabian head of state engaged in diplomatic and trade negotiations with the Japanese in a capacity that would probably never have materialized had it not been for the support of the Italians. The sentiments were echoed in the Arabic press, and Al Mokttam ran a piece which explained that Prince Hussein had extended 'his trip in the capital of the empire of the Rising Sun' in order to negotiate a possible JapaneseYemeni amity treaty to help the 'Islamic Front for the fight against communism', confirming

15 For more on Yemen, see John M. Willis, Unmaking north and south: cartographies of the Yemeni past, New York: Columbia University Press, 2012; Paul Dresch, A history of modern Yemen, Cambridge: Cambridge University Press, 2000.

16 'Lettera dell'Imam Yahya a Mussolini', Oriente Moderno, 17, 11, November 1937, pp. 570-1.

17 For example, Akio Kazama, 'Kaikyō raihai-dō no maku-shiki i-emen no ōji raichō (Inauguration ceremony of a mosque: prince of Yemen visits Japan)', Bungei shunjū, 16, 10, October 1938, pp. 172-81.

18 'Ipotesi sui motivi della sosta del Principe yeminita el-Husein a Tokyo', Oriente Moderno, 18, 8, August 1938, p. 447. 
the earlier suspicions of the Italian press. ${ }^{19}$ The Japanese were anxious to gain the patronage of important Muslim leaders in the Middle East and beyond, and they admired the Italians for doing so in a way that they considered successful. It was surely not lost on Japanese policy-makers that it was their connection to the Italians that gave them direct access to Prince Hussein in the first place.

Like the Italians, the Japanese had been working to gain the support of Muslims to parrot their propaganda and showcase their benevolence towards the Islamic world in lavish displays and prearranged statements. Also in attendance at the opening of the mosque was Pugong of the Manchu Aisin-Gioro lineage, which had ruled China as the Qing Dynasty from the mid seventeenth century until the early twentieth. Pugong was the younger and lesser-known cousin of the last emperor of China, Puyi. Puyi was forced to abdicate at the age of six in 1912, only to be lured out of exile by the Japanese with promises of reinstating him as 'emperor' of their puppet state, Manchukuo. His cousin Pugong had converted to Islam when he married a Hui Muslim woman named Huang Yongni. ${ }^{20}$ Puyi's Muslim-convert cousin was an asset to the Japanese: one of Puyi's direct relatives and a member of the imperial Manchu Aisin-Gioro lineage was not only a supporter of Islam but a Muslim himself. Pugong's presence at the opening of the Tokyo Mosque surely helped the Japanese to imagine themselves as legitimate protectors of Islam.

While in the imperial capital, representatives also participated in a variety of events meant to showcase Japanese modernity as well as the emperor's benevolent support for Islam. The guests' trip to Tokyo included visits to the zoo at Ueno Park and tours of the Japanese Imperial Naval Academy and a number of Japanese factories. ${ }^{21}$ In Tokyo, this group of Muslim men was able to witness for themselves how Japan imagined its changing role vis-à-vis the Islamic world after the outbreak of the Second Sino-Japanese War.

Following the opening of the Tokyo Mosque, there was a flurry of articles and editorials about Japan in newspapers around the Arab world. ${ }^{22}$ For instance, Dr Mohamed Fahmi published an editorial in the Egyptian newspaper Al Balagh regarding the burgeoning relationship between Egypt and Japan. He remarked that, after a number of delegates from Egypt had participated in the opening of the mosque, these men had had a chance to see for themselves how Muslims were treated in the Japanese empire. Fahmi was sympathetic to the Japanese treatment of Muslims and indicated to his readers that Japan could be a fruitful place for Muslim missionaries anxious to recruit new converts. He also explained that there were over two million Muslims living in Manchukuo and over twenty million living under the Japanese 'mandate', with mosques under the Japanese imperial gaze numbering over four hundred. ${ }^{23}$ The message was clear: the Japanese should be taken seriously in their efforts to appeal to Muslims.

It was the common concerns about the treatment of Muslims in Russian- and Britishcontrolled areas that initially piqued Middle Eastern interest in the Japanese imperial project.

19 Diplomatic Archives of the Ministry of Foreign Affairs of Japan, Tokyo, files relating to the Greater Japan Islam League (Dai Nihon kaikyō kyōkai o fukumu) (henceforth DAMFAJ, JMA), I-2-1-0, Folder 1.

20 Huang Yongni was a famous opera singer from Jinan and was better known by her stage name, Xue Yanqin.

21 Tang, Maijia xunli ji, p. 415.

22 DAMFAJ, JMA, I-2-1-0, Folder 1. These particular articles from Egyptian newspapers were translated from Arabic into French by the plenipotentiary minister of Egypt in Japan, Mr Hussein Bey (Abdul Khalek Hassouna Bey).

23 Ibid. 
Among Arabs and Turks, the Japanese were well respected as an Asian power who had defeated the Russians in 1905, and who stood up to Western imperialist powers in Asia. The opening of the Tokyo Mosque and the fanfare surrounding this event was a gesture to Muslims around the world, but the Japanese policies and interactions with Muslims did not develop in a vacuum. In part, they were made possible through connections with Muslims supported by the Germans, and in places with connections to Italy, such as Yemen. It is these encounters that provide insights into the 'alternative pattern[s] of international relations' made possible by cooperation between Muslims from around the world and the Axis powers. ${ }^{24}$

\section{Precedents and models for managing Muslims}

Imperial Japan drew upon a number of specific sources and models as their interest in Muslims on the mainland deepened after the establishment of Manchukuo in March 1932. For one, they followed familiar precedents for managing minorities in the Japanese empire, including late Meiji policies regarding Korean émigrés to the home islands and the Burakumin. ${ }^{25}$ Their handling of the naturalization of a small Muslim Tatar refugee population who arrived in Japan after fleeing the Bolsheviks also provided Japan with models for incorporating Muslim minorities into the imperial imagination. For example, in Figure 1, printed in 1936, young Tatars are apparently 'praying for the success of the Japanese-German alliance against Bolshevism'. Beyond these examples close to home, the Japanese further observed and learned from German and Italian mistakes and successes dealing with Muslim populations in North Africa, the Balkans, and the Middle East from before the First World War through to the end of the Second World War. ${ }^{26}$

Popular and well-circulated Japanese wartime periodicals such as New Asia (Shin Ajia) regularly carried articles about Italy and Germany. These articles introduced readers to Japan's allies and provided both historical and geopolitical information to a general reading audience. In 1941, Suzuki Tōmin wrote an in-depth article concerning Germany's and Italy's Near East policies and an analysis of how the Axis powers were handling the Muslim populations and fighting the Allies in North Africa and the Middle East. ${ }^{27}$ The article outlined the ways in which the Germans and the Italians provided Muslims with hope for independence from British imperialism through the extensive use of propaganda and goodwill gestures. Suzuki stressed the strategic importance of gaining the support of Muslims for German and Italian policies to succeed in North Africa and the Middle East, as well as the geopolitical importance of acquiring control of the Red Sea. With this article and others like it, Suzuki was attempting to legitimize Japan's use and manipulation of Muslims for their own purposes to readers who would have been up-to-date on current events in the Pacific. Driving home to readers that, without the support of Muslims in the Near East, a military victory for the Italians and the Germans would be unlikely, he made clear that the continued victories of the Japanese

24 Esenbel, 'Japan's global claims to Asia', p. 1165.

25 Jeffrey Paul Bayliss, On the margins of empire: Buraku and Korean identity in prewar and wartime Japan, Cambridge, MA: Harvard University Press, 2013.

26 DAMFAJ, JMA, I-2-1-0, Folder 2, 'Itaria no kaikyō seisaku (Italy's Muslim policy)' (henceforth 'Italy's Muslim policy').

27 Tōmin Suzuki, 'Do-I to Kintō seisaku (Germany, Italy and the Near East policies)', Shin Ajia (New Asia), 3, 3, March 1941, pp. 18-30. 


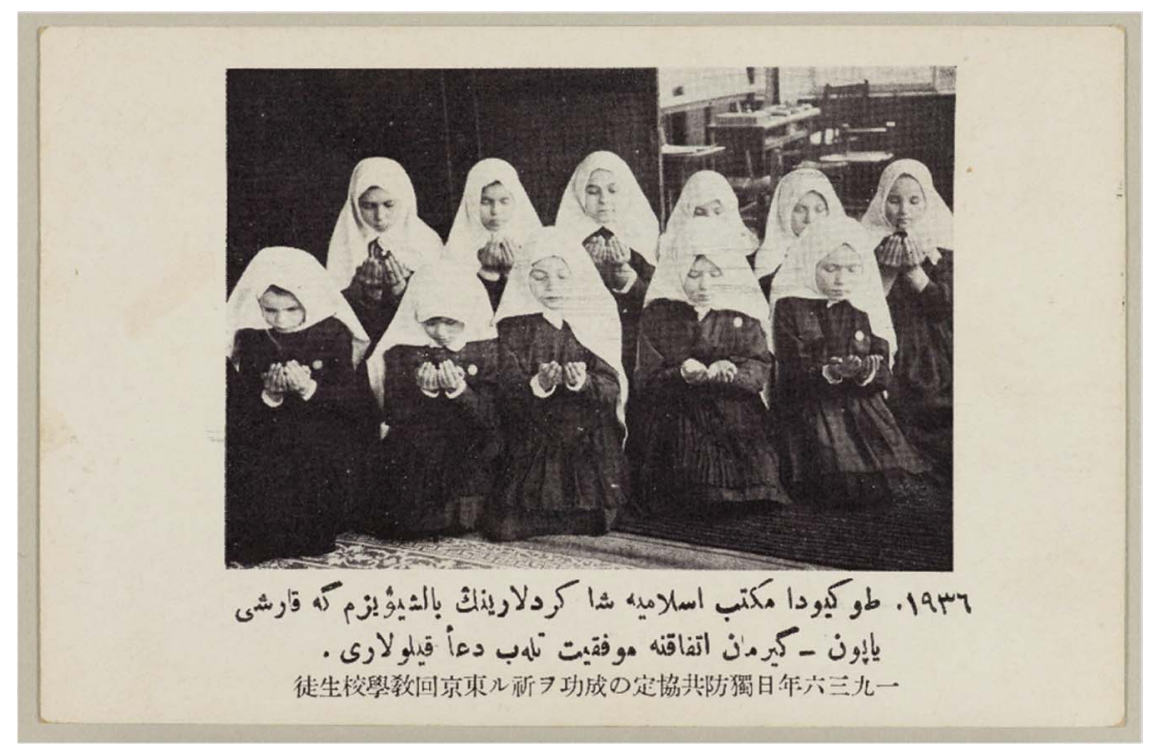

Figure 1. '1936, Pupils [Tatar girls] of the Islamic School in Tokyo pray for the success of the Japanese-German alliance against Bolshevism.' Source: online database of the Organization of Islamic Area Studies at Waseda University, 'Relationship with Kurban Ali' subsection, image 415. Reproduced with permission from the Waseda University Library Organization for Islamic Studies.

army would also rely on the support of the large Muslim populations in Southeast and East Asia. ${ }^{28}$

Japanese policies regarding Muslims closely mirrored German and Italian models, although the Japanese were quick to point out the many differences between the Germans, the Italians, and their own specific cases. There was a dramatic upturn in publications about Nazi Germany and Mussolini's Italy in the late 1930s in Japan, which intersected with Japanese policy-makers' growing interest in Islam. ${ }^{29}$ Japanese books about German history, for example the 1938 publication Gaikan doitsu shi (A general survey of German history), included such chapters as 'Isuramu to jūjigun' ('Islam and the Crusaders') to explain the deep, historical relationship that Nazi Germany had with the Islamic world. ${ }^{30}$ A common sentiment echoed by Japanese policy-makers was that there were two major differences between their experiences and approaches and those of Germany and Italy. First, Japanese imperialists argued that the Germans and the Italians had more experience with and knowledge about Islam, given their proximity to large Muslim populations in the Balkans and the Mediterranean. Second, the Japanese were aware that in areas under their control before the swift occupation of Southeast Asia that followed the bombing of Pearl Harbor, Muslims comprised a small minority of the population, unlike in the Ottoman empire in the First World War, in the Crimea, in parts of the

28 Ibid., pp. 27-30.

29 Hoffman, Fascist effect, introduction.

30 Rokurōbee Akiyama, Gaikan doitsu shi (A general survey of German history), Hakusuisha: Tokyo, 1938, pp. 69-74. 
Balkans, or in North Africa, where Muslims often made up the sizable majority. This presented a different set of challenges for Japan from those that the Italians and the Germans faced at the other end of the Eurasian continent. ${ }^{31}$ Finally, German anti-Jewish rhetoric played well to an Arab audience angered by Zionism and Jewish immigration to Palestine after the Balfour Declaration, but the Japanese found anti-Semitism difficult to come to terms with.

In the years leading up to the First World War, the German emperor, Kaiser Wilhelm II, had been deeply involved with the Ottoman empire. His endeavours proved a powerful case study for the Japanese, who hoped to learn from some of the Kaiser's over-ambitious political blunders. In the Kaiser's vision of Weltpolitik, he presented a concrete plan for uniting the East and West through Istanbul with the Berlin to Baghdad railroad. ${ }^{32}$ Wilhelm's plan of Drang nach Osten ('push eastward') consisted in part of a continental imperial drive into Ottoman territory that the Kaiser imagined would be more economically viable than joining the scramble for Africa. This vision also had an important cultural component: Wilhelm emphasized learning about Islam and spreading German culture to the Middle East. Later, the Nazis' political strategy for dealing with Islam - Islampolitik - was heavily influenced by the Kaiser's involvement with the Ottomans in the First World War. ${ }^{33}$ During the military campaigns in North Africa, the Nazis adapted their propaganda geared at Muslims to suit their military needs and urged Muslims to take their fate into their own hands and 'kill the Jews before they kill you'. ${ }^{34}$ Then, after the military failures in North Africa, the Nazis shifted their strategy to blame Jews for the war, driving home the notion that 'only an Axis victory would prevent Jews from world domination'. ${ }^{35}$

The Kaiser's vision for the Middle East ensured German access to the Arabian Gulf without reliance on the Suez Canal, and gave them direct access to India, the crown jewel of the British empire. ${ }^{36}$ As Wilhelm saw it, the Germans had not made aggressive advances into Muslim lands before the Triple Entente between Russia, France, and Great Britain in 1907. He understood this as an advantage for the Germans: as a latecomer to the game in Asia and North Africa, he attempted to use Muslim resentment towards imperial rule to foment dissent in these regions, all the while directing European powers' attention away from continental Europe with his plans for a railroad through Ottoman territories. Whether or not this was entirely successful is beside the point: Japanese policy-makers looked to and emulated this approach in their propaganda for explaining why Muslims in China should support their vision for a Greater East Asia. ${ }^{37}$ The Japanese, like the Germans before them, vilified the British and the French presence in the Middle East and East Asia among Muslim communities as a way to gain sympathy for their own imperial objectives. Japanese policy-makers familiar with the Middle East also observed and wrote about these German policies in order to create closer linkages with the Axis powers in the 1930s. The Japanese understood well the drawbacks of the Kaiser's plan and wrote about how they could learn from and apply the concepts of Drang nach Osten (Japanese: Dorangu naba osuten) on the mainland. ${ }^{38}$ A secret

31 'Italy's Muslim policy', p. 14.

32 Sean McMeekin, The Berlin-Baghdad express: the Ottoman empire and Germany's bid for world power, Cambridge, MA: Harvard University Press, 2010, pp. 1-2.

33 David Motadel, Islam and Nazi Germany's war, Cambridge, MA: Belknap Press of Harvard University, 2014, p. 16.

34 Herf, Nazi propaganda, pp. 89-150.

35 Ibid., p. 177.

36 McMeekin, Berlin-Baghdad express, p. 3.

37 'Italy's Muslim policy', p. 14.

38 Ibid. 
policy document published by the Japanese army in 1938 explained that this 'push eastward' concept was a term coined in the late nineteenth century to justify German expansion into Slavic lands. The document also described how Hitler appropriated the policy in the 1930s as a major tenet of Nazism, which involved the assimilation and Germanization of Slavic and non-German peoples. ${ }^{39}$

After visiting the Ottoman Sultan Abdul Hamid, Kaiser Wilhelm declared the German people to be the eternal friends of the Ottomans. Perhaps not fully understanding the implications of allying himself with the Sultan, Wilhelm was 'meddling in the affairs of other powers with Muslim subjects - not least French North Africa, Russian Central Asia, and the British Empire, which alone contained some 100 million Muslims spread out over British India, Egypt, and the Gulf States'. ${ }^{40} \mathrm{He}$ continued to travel throughout the Middle East and the Levant, visiting Jerusalem and Damascus, and came away with an orientalist appreciation for Islam. At one point he even declared that he could potentially convert; the declaration prompted references to 'Hajji Wilhelm' in local Arabic newspapers. This aggressive German vision presented the Kaiser as the benevolent protector of the Ottomans and antagonized colonial powers in the region. However, his bold move presented a powerful symbol of strength for Japanese policy-makers and army officials who were privy to the secret document explaining these events. Like Hajii Wilhelm before them, their ambitious visions meant that they would quickly have to figure out how to appeal to the large numbers of Muslims who came under their control.

In their efforts to mobilize Muslims, the gravest mistake that the Germans made in the First World War was to underestimate the backlash of backing an Ottoman call for jihad. On 11 November 1914, the Ottoman sheikh al-Islam Ürgüplü Hayri issued five fatwas with German support. In an elaborate ceremony three days later at the Fatih Mosque in Istanbul, Sultan Mehmed V declared it 'the duty of Muslims everywhere on earth to wage war on infidels'. ${ }^{41}$ However, from the outset there were serious problems with the fatwas. The 1914 fatwas declared a greater jihad, which was theologically unorthodox and was distinguished not by 'the terms of the declaration itself but [by] the open-ended selection of targets including Entente civilians, along with armies - and the pointed exemptions for German and Austro-Hungarian nationals, for which there was no precedent'. ${ }^{42}$ Not only were the theological grounds for this jihad highly questionable, but Mehmed V's declaration was also considered a symbolic last-ditch effort by the sultan to retain power despite his lack of legitimacy and authority in the eyes of many of his subjects. ${ }^{43}$

In retrospect the jihad is considered to have been a failed effort, but at the time it alarmed the British, the French, and the Russians, who decided to keep troops in the Middle East that could have been diverted to the front in Europe. ${ }^{44}$ Financially, the jihad also cost the Germans much more than they had anticipated because it needed to be advertised widely throughout the Muslim world. ${ }^{45}$ The Japanese learned from this: although they presented themselves as protectors of Islam, they never went as far as calling on Muslims to proclaim jihad (although there was talk about it late in the war in the Dutch East Indies).

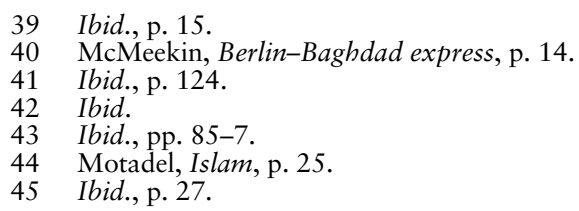


Having devoted a lot of energy and scholarly man-hours to understanding Islam and Islamic movements, the Japanese understood the contradictions of a non-Muslim power backing a call to jihad, and, although they were intent on being taken seriously as supporters of Islam and even played around with the idea of creating an independent Muslim state in north China (Hui-hui guo), they stopped short of enforcing theological decrees on Muslim populations living under their control and beyond in their war efforts.

During the interwar period, the German interest in Islam was predominantly scholarly. However, this changed suddenly with the outbreak of the Second World War in Europe. Hitler had Mein Kampf translated into Arabic in 1938, although other translations of it had appeared as early as 1934, and it was distributed in Arabic-speaking countries on the eve of the outbreak of war in Europe. There were problems, of course, with the virulent anti-Semitism in Hitler's writing, and the Nazis went through extensive propaganda efforts to 'convince Arabs that the Nuremburg race laws were not aimed at them'. ${ }^{46}$ The Nazis also used purported anti-Jewish verses in the Qur'an extensively in radio propaganda in Arabic to highlight how 'Nazi Germany and traditional Islam met on a shared terrain of political Manicheanism that divided the world into friends and enemies, believers and unbelievers, Germans and Muslims, on the one hand, and Jews, on the other'. ${ }^{47}$

During this same period, an increasing number of translations of the Qur'an appeared in Japanese. These translations are a noteworthy outcome of the intensified connections between Islam and Japan, as well as a testament to the skills of the translators, who had to make foreign Islamic texts relevant and relatable to Japanese readers. ${ }^{48}$ Han Martin Krämer argues that the number of translations of the Qur'an in the early twentieth century - six in total - can be traced to interest in Pan-Asian thought on the part of Japanese academics. Krämer points out that there were over 100,000 Qur'ans sold in translation in Japan in the 1930s, indicating that there was a growing interest among regular Japanese people about Islam that went beyond simply achieving foreign policy objectives. ${ }^{49}$ As Japanese scholars of Islam searched for words in their lexicon to convey the meaning of Arabic words, they struggled with how to deal with 'theologically charged concepts'. ${ }^{50}$ Translators wondered if they should 'make use of pre-existing religious terminology to facilitate understanding and evoke religious associations, should they resort to seemingly neutral terms to avoid such associations, or should they even try to invent new words not tainted with potentially misleading earlier notions'. ${ }^{51}$ For instance, the word kami (often translated as 'god'), which was deeply rooted in Japanese spiritual and religious traditions, was commonly used as a translation for Allah. Another 1938 translation rendered Allah as Ōkami, which generally refers to the Shinto goddess Amaterasu. Early translations of the Qur'an into Japanese represented a form of synthesis of Japanese religious expression and Islam. ${ }^{52}$ The issues of both translation and reception of the translations of concepts that were foreign and perhaps even offensive to readers plagued the Axis powers as they tried to make fascism appealing to a wider audience and Islam legible to non-believers.

46 Herf, Nazi propaganda, p. 20.

47 Ibid., p. 53.

48 Hans Martin Krämer, 'Pan-Asianism's religious undercurrents: the reception of Islam and translation of the Qur'ān in twentieth-century Japan', Journal of Asian Studies, 73, 3, 2014, pp. 619-21.

49 Selçuk Esenbel, Japan, Turkey, and the world of Islam: writings of Selçuk Esenbel, Leiden: Brill Global Oriental, 2011, p. 201.

50 Krämer, 'Pan-Asianism's religious undercurrents', p. 621.

51 Ibid.

52 Ibid., pp. 622, 627-31. 
In February 1941, the Germans landed in Tripoli to come to the aid of the Italians and at the same time intensified their 'religious blitz of the region with propaganda presenting Germans as friends of Islam'. ${ }^{53}$ They were careful to treat Muslim prisoners-of-war well, and allowed them religious freedoms denied other captives. For instance, the Reich ensured that Muslim captives had access to halal food and were allowed to pray five times a day. ${ }^{54}$ Muslims who served in the German Army or joined the Schutzstaffel (SS) in increasing numbers after 1941 were also provided with a mullah to accompany their battalions into battle, a point that the Nazis always emphasized in propaganda geared towards the Middle East.

As the Chinese Nationalists were counted among the friends of the Allies and were mounting their own propaganda efforts geared at Muslims in China, the Allies responded to Germany's growing interests in Islam with counter efforts. One leaflet distributed by the British in the Maghreb praised the " Chinese Muslims Warriors", who, under Chiang Kai-shek, were fighting the Axis in Asia'. ${ }^{55}$ Conversely, the Axis often produced Arab propaganda detailing how the British destroyed mosques and stole precious and ancient artefacts from the Arab world to fill their museums back in London. The Italians and the Germans also produced pro-Palestinian anti-Zionist propaganda that the Japanese credited for the underground agitation in the Levant and as one of the reasons for the Arab Revolt in 1936-37. ${ }^{56}$ Remarking on the successes of these efforts, the Japanese concluded that the Italian and the Nazi propaganda was generally successful in North Africa and the Middle East. ${ }^{57}$

In a Japanese-sponsored journal published in Chinese, an anonymous Chinese writer expressed admiration for the Germans for helping the Turks preserve the Hagia Sophia (Chinese: Haya Sufeya). He argued that the Japanese, like the Germans and the Italians, were busy preserving the minarets that came under their control and building new mosques for Muslim populations living within their empire. Another Japanese commentator noted that the Germans had built a large mosque in Berlin in 1923 for the many Turks, Egyptians, Persians, and Indians who lived there. ${ }^{58}$ Sino-Muslim collaborators such as the aforementioned Tang Yichen suggested to Japanese policy-makers that one of the surest ways to secure the loyalties of Muslims in north China was to build mosques and madrasahs in local communities. ${ }^{59}$ The preservation of sacred Islamic places, the rebuilding of mosques destroyed by the war, and the construction of mosques in the imperial metropoles - such as Berlin or Tokyo - were considered successful tactics for gaining the favour of Muslims, and the Japanese saw it as serving two main purposes: it gave them a sense of authority within Muslim communities, and it offered opportunities to vilify their enemies, especially the Soviets, who destroyed mosques throughout eastern Europe and Central Asia. In essence, both the Germans and the Japanese helped foster the re-entrenchment of Islamic communities through the rebuilding of mosques destroyed in the war. This was especially true for the Germans, who supported re-establishment of the waqf (a mortmain religious endowment in Islamic law) after the Soviets had abolished it in 1923 and seized all the associated assets and property. ${ }^{60}$ For the

53 Motadel, Islam, p. 73.

54 Ibid.

55 Ibid., p. 117.

56 'Italy's Muslim policy', p. 21.

57 Ibid., p. 33.

58 Juzi, 'Riben chuangli huijiao xiehui zancheng (Japanese approval of the Islamic Association)', Huiguang, 1, 1, 1924 , p. 50.

59 'Huijiao lianzong hui jianshe libaitang (Muslim Federation builds a mosque)', Islam, 1, 6, 1938, p. 43.

60 Motadel, Islam, pp. 160-1. 
Germans and the Japanese, the costs of these reconstruction and building projects were small compared to their propaganda value.

The Japanese also tried to connect themselves to the Germans and the Italians in some rather precarious ways in order to bolster their propaganda efforts among Muslim populations in China. A number of Japanese observers commented on the favourable German treatment of Muslim communities in German-occupied Qingdao (Tsingtao) prior to the Japanese takeover of the region after the First World War. One writer remarked that, as a result of Germany's positive treatment of Muslims in Shandong, the Japanese had the Germans to thank for their continued success interacting with Muslim populations there. ${ }^{61}$ This far-fetched connection from the German presence in Qingdao to the Japanese presence there is a tenuous one, but it served a rhetorical purpose: although there was no mention of the Japanese having received Qingdao as part of the spoils of war after the defeat of Germany in the First World War, the author was suggesting that there was an inherent connection in the ways that the Germans and the Japanese treated Muslims, and that the Japanese had benefited from German benevolence towards Muslims in Qingdao. These claims could simply be dismissed as wartime propaganda, but the main point should not be overlooked: the Japanese were looking for ways to tie their own involvement with Muslims directly to German policies.

Perhaps one of the most perplexing questions raised by this research is why Japanese policy advisers writing for a military audience chose to present Italian and German colonial designs in North Africa and the Middle East as successful because, by almost all accounts, they were a ghastly failure. Their motivations for doing so were less about the Italians and Nazis themselves, and more about the ways in which Japanese militarists and wartime policy-makers wanted to create direct connections to both the Italians and the Germans through issues that all three powers faced. These motivations become apparent when Japanese policy-makers outlined the relationship between Italy and the Islamic world and explained in detail how Italy governed Muslim populations throughout its empire. ${ }^{62}$ As in Japan, there were very few Muslims living in Italy in the first years of the twentieth century, and, like the Germans, the Italians were latecomers to the scramble for Africa. Comparing their situation to the Italians, the Japanese deemed both of these factors advantageous. They admired the Italians, who with their continuing support for Imam Yahya in Yemen had managed to secure a foothold closer to Mecca than either the British or the Americans would have liked.

After describing Italian colonial expansion into Africa following the opening of the Suez Canal in 1869, 'Italy's Muslim policy' goes on to single out Libya as the place where Italian policies and strategies were the most successful. ${ }^{63}$ Although this might seem counter-intuitive to the modern reader, Japanese militarists noted that, after the First World War, the Italians began developing industries in Libya (particularly smelting and ironworks), and also instituted the active promotion of cultural policies that increased mutual understanding between Italian colonialists and local Muslims (Japanese: yūkō-teki bunka seisaku). ${ }^{64}$ The Japanese noted that, as part of this plan to promote cultural appreciation, the Italians funded the building of mosques, schools, hospitals, bridges, and roads, which were all tangible gauges of the Italian presence in Libya. According to the Japanese military officials, locals perceived

61 'Guanyu Dongjing qingzhensi luocheng yu li zhi suowen (Regarding the completion and opening of the Tokyo Mosque)', Yiguang, 97, 1939, pp. 11-13.

62 'Italy's Muslim policy', p. 14.

63 Ibid., p. 16.

64 Ibid. 
these infrastructure developments as beneficial to their local communities and economies. They argued that these projects not only changed the physical landscape of Libya but also provided jobs for locals, resulting in a higher standard of living among certain segments of the population. The report claimed that in a few short years the Italians had transformed their reputation in Libya and were now seen in a much more positive light than they had been before. ${ }^{65}$ This model was similar to the plans adopted by the Japanese in north China.

Being able to justify their investment in the region by pointing to what they considered to be a successful Italian precedent surely helped bolster the support that Japanese policy-makers working on Muslim issues in China hoped to gain among the larger spectrum of empirebuilding projects. 'Italy's Muslim policy' concluded that, unlike the British, who were intent on dominating Muslims for the purpose of extracting as much oil as possible from the Middle East, the Italians were trying to cooperate with Muslims for their mutual benefit. It was from this 'cooperative model' that Japanese analysts thought they could learn the most: in their eyes, such a model led to both cultural understanding and economic development which would ensure a long and sustained relationship of mutual dependence. The report concluded that, by following the lead of the Italians, the Japanese could make similar inroads among the Muslim populations who had recently come under their direct control in north China.

Hand in hand with Italian developmental policies, the Japanese observed that Mussolini had made a trip to Tripoli to declare himself 'the protector of Islam' (Japanese: kaikyō no hogo-sha). In Arabic, Mussolini was called 'al-sayf al-Islam' ('the sword of Islam'), but this differs from the Japanese translation, which clearly calls him the 'protector' of Islam. During this proclamation, the Duce made promises about the beneficial relationship between fascism and Islam for Muslims throughout the region. Japanese militarists highlighted how the Italians stressed in their propaganda efforts in North Africa that the French and the British were the real enemies of Muslims. In order to present themselves as legitimate liberators, the Italians drew on their common connections as Mediterranean peoples: while the French and the British hailed from distant places, it was posited that the Italians were Mediterranean people with a close cultural connection to North Africans dating back to the Roman empire. ${ }^{66}$ Like their European counterparts, the Japanese looked for tangible ways to connect themselves to Muslims from China in order to bolster their legitimacy. For example, a number of Japanese intellectuals claimed that Japanese connections to Islam in China could be traced back to seminal Sino-Muslim texts written in the early eighteenth century known as the Han Kitab (Chinese: Han Ketabu). The Japanese argued that these syncretic Chinese texts which explored the relationship between Confucianism and Islam had been read by Japanese scholars during the Tokugawa era (1603-1867), resulting in an intellectual appreciation for the Chinese variations of Islam dating back as far as the seventeenth century. ${ }^{67}$ Although they were not able to draw on the historical memory of the Roman empire, the Japanese looked for ways to bolster their legitimacy through the invention of historical narratives of connectivity similar to the way in which the Italians drew on the Roman Mediterranean legacy.

The Japanese believed that, in order show their support for Muslims suffering at the hands of the French and the British, the Italians had invited Muslim students to Rome from such places as India, China, and Afghanistan to participate in the Asian Student Congress (Japanese:

66 Ibid.

67 Juzi, 'Riben chuangli huijiao xiehui zancheng', pp. 50-2. 
Ajia gakusei Kaigi) in 1933. Mussolini had addressed some five hundred students with a rousing speech about the Italian Fascists' plans to give Muslims a leg-up to free themselves from the clutches of colonialism. Alongside this successful bid to bring Muslim students to study in Rome (which was a relatively inexpensive policy with high return on investment), the Italians were also exporting their vision of fascist youth culture to their colonies in North Africa, where they established a number of Green Shirt organizations (Japanese: Midori Shatsu Tō). The Japanese reported that young Muslims happily joined because, as members of the Green Shirts, they were presented with the potential opportunity to study in Rome. ${ }^{68}$ Japanese militarists mentioned that this would be a good tactic for recruiting young and impressionable Muslims into their own camp by replicating this model and that they should start inviting Muslim students from all over East Asia to study in Tokyo.

Only four years later, the Italians were praising the Japanese efforts to bring students from Arab nations to the 'Young Asia' Congress in Tokyo. Oriente Moderno reported that the Japanese had assembled over 'two hundred representatives from India, Siam, Inner Mongolia, Arab nations, northern China, Manchukuo, etc.' The students, together with their hosts, issued the following statement regarding the most pressing issues facing the attendees:

Opposing European and American interference in the Sino-Japanese conflict; insisting the British Government cease supplying arms to China by way of Hong Kong; advising the Nanking Government to come to an agreement with Japan for an Asian Risorgimento; inviting the Indians to begin participating immediately in the movement to liberate Asia; inviting Asian States to join the Anti-communist Pact as soon as possible; and thanking Italy and Germany, who have united their forces to oppose communism. ${ }^{69}$

This fascinating notion of an 'Asian Risorgimento' to unify China was likely used as a rhetorical device to connect Italian readers to the difficulties and experiences of the consolidation of power on the Chinese mainland. Beyond this, the appeals to youth across Asia and the Middle East, albeit not specifically Muslim youth, were reminiscent of the youth rallies held by Mussolini in Rome in the early 1930s. The amount of coordination that rallies like this would have required during wartime is staggering, and the fact that the Japanese were willing to bring all these students to Tokyo is a testament to their desire to be taken seriously as a player in global geopolitics. Although these types of events are often overlooked in the larger policy objectives and goals of the Axis powers, their importance in shaping the relationship between the three powers, as well as in providing connections between individuals and spaces for burgeoning anti-colonial movements from all over the Eurasian continent and North Africa, should be acknowledged.

The Germans, Italians, and Japanese all broadcast radio programmes from Berlin, Rome, and Tokyo respectively to Muslim populations in a large variety of languages, and they were generally considered to be more successful than the Allies' attempts to do the same. ${ }^{70}$ Italy began broadcasting in the Middle East in 1935. Both the melodramatic tone and the vehemently anti-British and anti-French propaganda of their stations were appealing to Arabs. Later, the Germans (broadcasting from the station located in Zeesen, south of Berlin) would

68 'Italy's Muslim policy', p. 27.

69 'Rappresentanti di paesi arabi al Congresso "Giovane Asia" di Tokyo. Ordini del giorno (Representatives of Arab nations at the "Young Asia" Congress in Tokyo: orders of the day)', Oriente Moderno, 17, 12, December 1937, p. 597. Translated from the Iraqi newspaper al-Bilad, 21 November 1937.

70 Arsenian, 'Wartime propaganda', pp. 418-20. 
emulate the tone and content of Italian Arabic radio in North Africa. ${ }^{71}$ The Japanese also emulated the Italians, with varied success, in their radio broadcasts to Arabic, Persian, Turkish, and Pashto speakers throughout Eurasia. ${ }^{72}$ Afghan students returning to Kabul after studying in Japan in 1943 remarked on the considerable number of 'Tadjik [sic], Kazak [sic], and Turkmen students in Japanese institutions', and that the Japanese-controlled radio in China broadcast in 'several Central Asiatic tongues'. ${ }^{73}$

In their earlier radio broadcasts, the Germans tended to emphasize anti-Soviet messages, interspersed with pro-nationalistic messages directed at Muslim populations in the Balkans and Middle East, whereas the Japanese tended to emphasize their 'liberation' of the Muslim populations throughout Asia, as well as their role as protectors of 'Oriental' peoples around the globe. ${ }^{74}$ Japanese broadcasts also devoted attention to Sino-Muslim collaborators and their efforts to defeat the Chinese Nationalists on the mainland. For instance, in July 1943 a radio broadcast from Tokyo announced that the famous Muslim Lieutenant from Shanxi, Ma Zhong, had surrendered to the Japanese near Taiyuan. Ma was a known anti-CCP agitator and supposedly pledged 'that he would offer his services for the construction of New China ... under the able policy of Wang Ching-wei [Wang Jingwei] and his collaborationist government in Nanjing', although this 'confession' was likely taken under duress. ${ }^{75}$

Even though the Axis powers were employing similar tactics, the differences in content highlight some of the discrepancies in the approaches to appeal to Muslim listeners. Only three years after the war ended, Seth Arsenian noted that, although the Axis powers had lost the war, their radio broadcasts had helped germinate the 'campaign of hate' against the imperial powers in the Middle East and that the 'accusations which the Axis propagandists directed against the Allied nations will continue to have their subtle effect for some time to come'. ${ }^{76}$ These sentiments are echoed by Jeffrey Herf, who concludes that Nazi propaganda for the Middle East emanating from wartime Berlin produced a 'remarkable political and ideological synthesis ... of Nazism, Arab nationalism, and fundamentalist Islam' which still resonates to this day. ${ }^{77}$

There was a 'considerable degree of Japanese collaboration with Germany on Muslim policy and a corresponding delimitation of spheres of overt leadership' concerning Muslim populations. ${ }^{78}$ By 1943, it was clear that the Germans had adopted the obviously more anti-Jewish, anti-Soviet stance, whereas the Japanese were gearing their efforts at anti-British and anti-American propaganda. In part because of the Japanese-Soviet neutrality pact, Japanese policy-makers focused their propaganda towards Southeast Asia and India and 'communism' in general, whereas the Nazis took the lead in propaganda efforts aimed at the Soviet Union and Jews. However, this delimitation of zones of influence did not impede cooperation between the Japanese and the Germans. For example, the Germans relied heavily on important Japanese connections and informants in Afghanistan. As mentioned, the Japanese had a deep and developed spy network in addition to their consular services in Afghanistan. Robert Crews has recently pointed out that it was only after the Second World War that America would 'displace' Germany as 'the leading donor underwriting Afghan

71 Ibid.

72 Ibid., pp. 419-21.

73 NARA, OSS, RG 226 2-4-3 890.2.

74 Arsenian, 'Wartime propaganda', pp. 419-21.

75 NARA, OSS, RG 226 190-3-4-3 890.1, Box 14 890.0.

76 Arsenian, 'Wartime propaganda in the Middle East', pp. 419-21.

77 Herf, Nazi propaganda, p. 260.

78 NARA, OSS, RG 226 2-4-3 890.2. 
development projects'. ${ }^{79}$ When a plot was uncovered to overthrow the Soviet rule in Bukhara in April 1943, it was determined that the anti-Soviet agents behind the plan were 'elements with Bozkurt [Grey Wolf] connections' from northern Afghanistan 'long known for their Japanese connections'. In the first draft of an OSS field report discussing this situation, the following sentence was scratched out and not included in the final draft of the confidential dossier: 'When confronted by the Afghan Government with his part in the Bokharan [sic] plot, the German Minister, Pilger, instead of denying the charge, merely promised to stay out of such activities in the future. ${ }^{, 80}$

The downplaying of covert Japanese activities among Muslim populations in Afghanistan in these plots was likely in the interest of preserving Soviet neutrality against Japan during the war. However, it is clear that the Germans were using Japanese informants and connections that they had worked to cultivate in order to stir up anti-Soviet dissent in Central Asia. In a similar vein, the Germans and the Japanese had also reached 'an understanding' regarding what to do about the exiled Indian Nationalist leader Chandra Bose. Bose, who had been an on-and-off resident of Japan since 1933, travelled to Europe in 1943 under German protection. Following his arrival in Berlin, American observers remarked that the 'speedy rise of numerous Muslim organizations in Berlin during 1943 [was] reminiscent of similar activities in Tokyo between 1933 to $1939{ }^{\prime}{ }^{81}$

\section{The Chinese Nationalists respond and react to Japan's Islamic policies}

As noted, the main difference between both Germany's and Italy's Muslim initiatives and those of Japan was that the Muslim populations that Japan encountered in China were usually a relatively small proportion of the larger population. The Japanese thus had an interest in perpetuating difference in China, especially between Sino-Muslims and their Han Chinese neighbours. The Japanese fostered ethnic and community cleavages by promoting pan-Islamism and bonds with the larger global community of Muslim believers, fabricating narratives which projected the relationships between Japan and Muslim populations as peaceful and historically significant, and cultivating a sense that Sino-Muslims were a distinct and oppressed group. Japanese policy-makers realized that they needed to present Muslims throughout Asia with opportunities to begin to reconceptualize their relationships to the greater Islamic world, which would in turn be beneficial to the Japanese themselves.

Like the other Allied powers, the Chinese Nationalists worked hard to counter proJapanese, anti-GMD messages disseminated throughout the Islamic world by pro-Japanese Muslims. As a reaction to their mounting concern over successful Japanese-sponsored missions abroad, the Nationalists sent a number of goodwill missions to India and Egypt throughout the war. The Nationalists also strengthened their diplomatic ties to the Middle East during the Second World War. Before Pearl Harbor, they only had official diplomatic relations with Turkey. By March 1942, they had broadened these connections to include a consular office in

79 Robert Crews, Afghan modern: the history of a global nation, Cambridge, MA: Belknap Press of Harvard University, 2015 , p. 8.

80 NARA, OSS, RG 226 2-4-3 890.2.

81 NARA, OSS, RG 226 2-4-3 890.2. 
Iraq and an exchange of ministers with Egypt and Iran. ${ }^{82}$ They also sent a number of students who were studying at Al-Azhar in Egypt to intercept the Japanese-sponsored hajj led by Tang Yichen. ${ }^{83}$ In March 1942, the GMD-supported Chinese Islamic National Salvation Federation sent the Sino-Muslim Wu Qianxun (also known as Osman K. H. Woo) on a goodwill mission to India. Wu had recently returned from another goodwill mission to Malaya with the prominent Sino-Muslim General Bai Chongxi (who later retreated to Taiwan with Chiang Kai-shek and helped establish the Chinese Muslim Association in Taipei). ${ }^{84}$ The men spent almost five months in India, visiting Bombay, Delhi, Lahore, Allahabad, and Rawalpindi. From India, the group travelled through Afghanistan and Iran, where they spread anti-Japanese messages. In late December, they journeyed to Tehran and then on to Baghdad, where they were received as guests of the Iraqi government for a number of weeks. Following their trip, a German-supported newspaper published in Budapest reported that Wu's propaganda efforts in the Middle East were 'so successful' that 'they contributed to Iraq's declaration of war on the Axis on January 16, 1943, ${ }^{85}$ The success of Wu's efforts lay in the power of his benefactors - the British and the Americans - and their pre-existing connections throughout India and the Middle East, as well as in his credibility as a well-known Chinese Nationalist Muslim.

Chiang Kai-shek worked hard to secure the support of the international community in his drive to attempt to expel the Japanese from the mainland with his own foreign propaganda campaigns and goodwill missions. ${ }^{86}$ These campaigns often highlighted his growing concern over connections between the Japanese and the Italians, and even prompted him to send Chen Gongbo, a high-ranking government official who was in charge of domestic propaganda, on a goodwill trip to Italy to try to 'win sympathy for China from the Mussolini government'. ${ }^{87}$ These successes demonstrate that, along with the Chinese Nationalists, the British and the Americans had an interest in destroying the credibility of the Axis powers among Muslim populations and were just as capable as their enemies of deploying prominent delegations of Muslims. It was the connections between the Chinese, the Americans, and the British that made these types of endeavours possible; without the support of well-respected Chinese Muslims to help them in their anti-Japanese propaganda efforts, it is unlikely that the Allies could have countered Japanese appeals so successfully.

The connections between the Axis powers concerning Muslims did not go unreported in pro-Nationalist publications throughout Free China. For instance, the journalist Ren Wenbo reported on a conversation where he questioned an older Muslim man living under occupation about his pro-Japanese proclivities. To Ren, who was working undercover in the Japaneseoccupied territories, the old man became a proxy through which he filtered his conclusions about Japanese successes convincing Muslims living in China's borderlands that communism was their real enemy. Ren's main conclusion was that Japanese propaganda was actually quite successful in China's northern borderlands and he urged Chiang's government to respond with their own amped-up message to Muslims living in China's border regions. As Ren saw it,

82 NARA, OSS, RG 226 190-3-4-3 890.1.

83 Tang, Maijia xunli $i$, pp. 312-14.

84 NARA, OSS, RG 226 190-3-4-3 890.2, 'Japanese infiltration among Muslims in China', July 1944.

85 NARA, OSS, RG 226 190-3-4-3 890.2.

86 Shuge Wei, 'News as a weapon: Hollington Tong and the formation of the Guomindang centralized foreign propaganda system, 1937-1938', Twentieth-Century China, 39, 2, May 2014, pp. 118-19.

Ibid., pp. 127-30. 
the 'three fascist powers' geared well-received propaganda towards Muslims with a strong anti-communist message. ${ }^{88}$ To drive this point home, he relied on a quote from the old Muslim man: 'Look! Japan, Italy, and Germany - all three together waving a flag! They have a strong relationship: they resist communism, and they help hinder the progress of communism. We see this as important. ${ }^{89}$ Speaking candidly about the Nationalists, the old man went on to tell Ren that they were not perceived in a favourable light by many Muslims: 'You [the GMD] wrecked and destroyed our Muslim population! You killed our Imams [Chinese: Ahong], ruined our standard of living, and you have forced us to perform a juggling act [Chinese: baxi]. ${ }^{90}$ Presumably, this 'juggling act' was the delicate balance that Muslims who lived in north-west China 'performed' between the Soviet, GMD, CCP, British, local, and Japanese interests in the region. In essence, the old man was blaming the GMD for their ineptitude and failures, and saying that, because of their inability to govern, many Muslims in the region chose the Axis over the Allies for practical and pragmatic reasons.

\section{Beyond China: Japanese Islamic policy and imperial expansion in the Pacific}

After Pearl Harbor, Japan made incredible territorial gains in a very short time. During this time, they also had the opportunity to extrapolate from their experiences with Muslims in Manchukuo and attempted to implement policies that were working in north China among Muslim populations throughout their growing empire. Unlike in Manchukuo, where Muslims were only a small minority of the population, in some places that came under their control such as the Dutch East Indies, Malaya, and parts of the Philippines - Muslims made up a majority of the population. This meant that Japanese policy-makers had to adapt and adjust their policies accordingly in these places. They also continued many of their policy initiatives that had been successful in the earlier years of the war, such as bringing Muslim students from around the Japanese empire to study in Tokyo, as illustrated in Figure 2. In both Malaya and the Dutch East Indies, after the Japanese occupied and interned colonial officials they worked quickly to develop relationships with opponents of British and Dutch rule. Aiko Kurasawa has characterized Japanese policy in the Dutch East Indies as a combination of 'control' and 'mobilization'. 91 She argues that the Japanese occupation displaced some of the indigenous power structures that had long been supported by the Dutch, allowing for social and political change that transcended the Japanese occupation into the post-war era. It also legitimized young Muslim nationalists, such as Sukarno and Muhammad Hatta, whose anti-imperialist activities had resulted in suppression and imprisonment by the Dutch. The Japanese influence in the Dutch East Indies among Muslims was obviously shorter and less impactful than in north China, where fifteen years of formal occupation allowed Japanese militarists to implement long-term policies; nonetheless, it is generally agreed that it had a lasting impact on Indonesia and post-war decolonization movements.

88 Wenbo Ren, 'Huijiao shijie de mogui huodong (The [Japanese] devil's movements in the Islamic world)', Chinese Islamic National Salvation Federation Journal, 1, 8, 1939, pp. 34-7.

89 Ibid., p. 35.

90 Ibid.

91 Aiko Inomata Kurasawa, 'Mobilization and control: a study of social change in rural Java, 1942-1945', $\mathrm{PhD}$ thesis, Cornell University, 1988. 


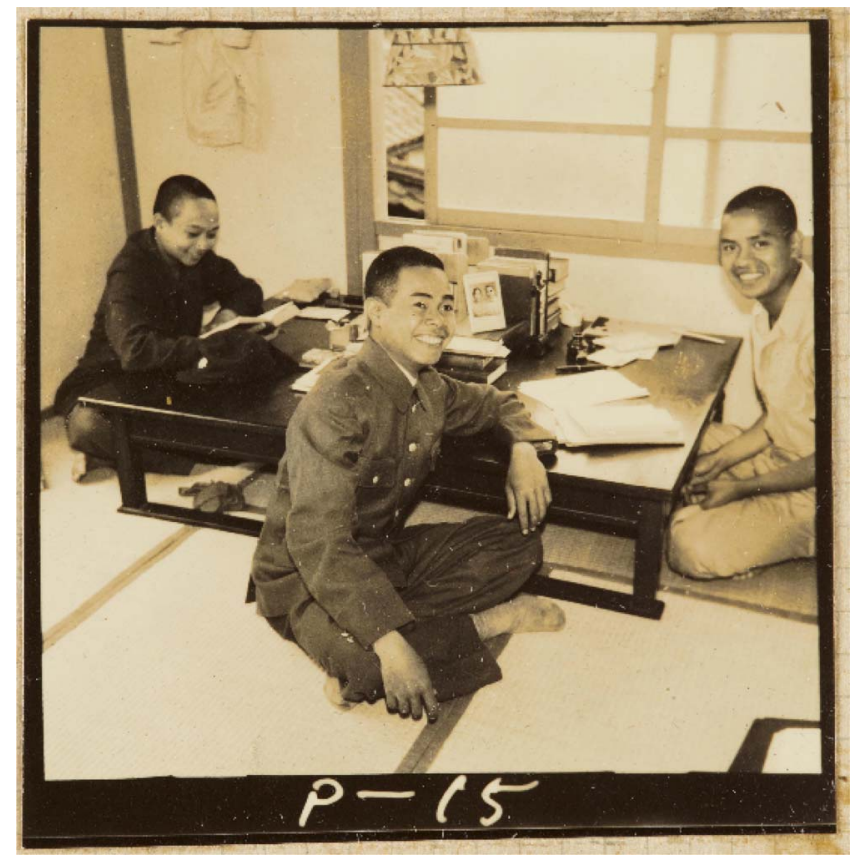

Figure 2. Photo of Moro (Philipino Muslim minority) foreign students, Tokyo, late 1943. Source: online database of the Organization of Islamic Area Studies at Waseda University, 'Abubakar Halim's photos' subsection, image 1268(15). Reproduced with permission from the Waseda University Library Organization for Islamic Studies.

Before the Japanese occupied the Dutch East Indies, Dutch colonizers were attempting to work with different Muslim groups by promoting cooperation through educational incentives. On the eve of the occupation, the Dutch were facing mounting opposition from a number of Islamic reform groups who hoped to 'steer the Islamic movement in the direction of hostile noncooperation'. 92 The Dutch orientalist Christiaan Snouck Hurgronje had long advocated embarking on joint ventures between Dutch colonists and Muslim communities in Indonesia as a way to foster cooperation and reduce animosities. ${ }^{93}$ Islamic organizations in Indonesia founded by Muslim reformers influenced by Islamic modernists like Rashid Rida, such as Muhammadiyah (founded 1912) began by opening new-style Islamic schools with modern curriculums. Many of the early Muhammadiyah schools received funding from the Dutch government, who also saw value in the idea of a modern, educated Islamic elite. ${ }^{94}$ However, by the mid 1920s there was a backlash in the Muhammadiyah madrasahs, and a number of Islamic reformers began to shun the schools. Though initially wary of Japanese intentions, after the invasion of Java in March 1942 Muhammadiyah leaders were won over by the stated policy of 'respect for religion'. In the early months of the occupation the Muhammadiyah

92 Harry J. Benda, The crescent and the rising sun: Indonesian Islam under the Japanese occupation, 1942-1945, The Hague: W. Van Hoeve Ltd, 1958, p. 99.

93 Ibid., p. 49.

94 Ibid., pp. 44-7. 
chairman, Kyai Haji Mas Mansur, called for 'Muslims everywhere' to 'unite and sacrifice to follow the Japanese Army and sweep Allied filth from Asia, even the entire world'. 95

Because of the high illiteracy rates and the relatively small Japanese occupation force in the Dutch East Indies, the army relied on and used shortwave radio broadcasts to spread their propaganda throughout Java and Sumatra. Through the Department of Propaganda (Japanese: senbu kōsaku), the Japanese quickly started issuing broadcasts intended to 'grasp people's minds' (Japanese: minshin ha'aku) and to 'indoctrinate and tame' (Japanese: senbukōsaku). ${ }^{96}$ They recruited Muslim intellectuals and politicians for radio broadcasts, giving Indonesian leaders such as Hatta and Sukarno the chance to talk directly to the Indonesian people. This was a dramatic departure from Dutch policy, and Kurasawa claims that it 'was the result of the influence of Nazi Germany' on Japanese policy. ${ }^{97}$ In February 1941, the Nazis had instituted similar policies, giving prominent anti-British, anti-Jewish Muslims such as Chandra Bose, the pro-Axis Iraqi Rashid Ali-Kilani, and the Mufti of Jerusalem extended airtime on their radio broadcasts to the Arab world from Zeesen. ${ }^{98}$

At the beginning of the occupation, Islamists on Java and Sumatra were sympathetic to the Axis powers because of the continued German support for people such as Amin al-Husayni, who was living in exile from Palestine in Berlin; many also saw the Japanese as liberators. ${ }^{99}$ In the occupied Dutch East Indies, the Japanese provided a new political platform for emerging Muslim nationalists and the ulema, leading to the increased politicization of Islam in the region. ${ }^{100}$ The Japanese had already been approaching Muslim associations who were disgruntled with Dutch rule in Java and Sumatra as early as 1940. Before that, Japanese militarists employed agents working in the archipelago to spread propaganda about the similarities between Shinto and Islam and highlighted Japan's role as saviour from Western imperialism in Asia. Their efforts did not go unnoticed and, immediately after the Japanese occupation of Java and Sumatra, a number of anti-Dutch Islamic resistance groups parroted the Japanese visions for a Greater East Asia and pledged to support them. ${ }^{101}$ In essence, the Japanese were able to tap into pre-existing suppressed networks on Java and Sumatra in order to garner support from anti-Dutch Muslim groups who had already been operating since the 1920s or before.

The Japanese curried favours with local Muslim elites who held sway over the large and devout rural populations of Muslims on Sumatra and Java in the same way as they had in north China. However, rather than using the tactics of highlighting difference between the Hui and the Han, they attempted to foster cooperation among all Muslims who opposed Dutch rule. To demonstrate their benevolence and support for Islam, the Japanese flew prominent Muslim leaders to Tokyo in November 1943 to participate in a bid to win support for the Japanese occupation government on the islands. ${ }^{102}$ These policies were not new and, as in other places throughout their empire, Japanese militarists appealed to Muslims in Jakarta through a sense of compassion coupled with a strong anti-Western colonial message. By this time, the Japanese

95 Yasuko Kobayashi, 'Islam during the Japanese occupation', in Peter Post, William H. Frederick, Iris Heidebrink, and Shigeru Sato, eds., The encyclopedia of Indonesia in the Pacific War, Leiden: Brill, 2010, p. 305; William H. Frederick., 'Mansur, Kyai Haji Mas', in ibid., p. 547.

96 Kurasawa, 'Mobilization and control', p. 318.

97 Ibid., p. 366.

98 Herf, Nazi propaganda, p. 38.

99 Yasuko Kobayashi, 'Kyai and Japanese military', Studia Islamika, 4, 3, 1997, pp. 70-2.

100 Ibid., p. 87.

101 Benda, Crescent, pp. 104-5.

102 Ibid., p. 138. 
were seasoned veterans who knew how to provide favours to Muslim leaders in exchange for their loyalty, however shallow and tenuous. They had tried and tested these policies in their own empire, as well as having watched and carefully observed German and Italian successes and failures with similar issues throughout the Islamic world.

\section{Conclusions}

The Second World War and the post-war period of decolonization that followed were not discrete events but rather an ongoing and contested process between state actors and individuals. ${ }^{103}$ Reducing the Axis involvement with Muslims to a brief and failed wartime interregnum downplays the lasting impact that Axis policies, propaganda, infrastructure, and ideology had on Muslims throughout the Islamic world. For their part, the Axis promoted connections between Muslims, and in some cases these relationships lasted well beyond the war. Japanese rule in places as far afield as Java and north China was instrumental in bringing Muslim leaders together and introducing them to each other. In many cases, it was these leaders who became 'the principal inheritors of political authority once Japanese control had collapsed'. ${ }^{104}$ Although Axis involvement with Islamists and Muslim leaders around the world was brief, and the implementation of policy often uneven, the legacies of global fascist imperialism lived on, from the newly politicized Muslims who advocated for freedom from Dutch rule in Indonesia to the strains of Anti-Jewish and Anti-Zionist ideology that were deeply entrenched in Arab nationalist discourses in the 1950s and 1960s. ${ }^{105}$

In ways that might seem counter-intuitive to contemporary readers, the Axis powers provided the space for young Muslim politicians to make their way 'into public life and officially sanctioned positions of prestige, if not actual power'. ${ }^{106}$ Through their constant 'ritual rejection of Western individualism and liberalism', the Japanese not only introduced many of the Muslim leaders of the post-war era to each other at events in Tokyo, but also gave them the new vocabulary they needed to begin to free themselves from Western imperialism. ${ }^{107}$ Paired with training in guerrilla warfare, which the Japanese had learned in ongoing battles with Mao Zedong and the Chinese communists, post-war Islamists in Southeast Asia were armed with a new political vocabulary and trained insurgents for their next battle: decolonization. This was not dissimilar to the ways in which Nazi ideology and anti-Jewish hatred influenced radical Arab nationalism in the years after the war: 'The collaboration, though short-lived, left traces behind and lineages outside Europe that persisted long after the Nazi regime was destroyed and Nazi ideology discredited in Europe. ${ }^{\text {108 }}$

The exploration of these connections is just beginning, and Muslims living around the world - from Brooklyn to Bangladesh to the Balkans - might just provide a means to understand the interconnectivity between the ideologies and the actions of the Axis powers during the Second World War in new ways. The short yet deeply influential period of Axis

103 Fredrick Cooper, Citizenship between empire and nation: remaking France and French Africa, 1945-1960, Princeton, NJ: Princeton University Press, 2014, introduction.

104 Benda, Crescent, p. 200.

105 Herf, Nazi propaganda, prelude.

106 Harry Benda, 'The Japanese interregnum in Southeast Asia', in Grant Goodman, ed., Imperial Japan and Asia: a reassessment, New York: Columbia University Press, 1967, pp. 74-7.

107 Anthony Reid, 'Indonesia: from briefcase to samurai sword', in Alfred McCoy, ed., Southeast Asia under Japanese occupation, New Haven, CT: Yale University Press, 1980, p. 26. Herf, Nazi propaganda, p. 2. 
colonization, infiltration, and occupation into the Islamic world had a profound impact on the social and political fabric of the Middle East, Southeast Asia, and parts of China for a long time after the Axis powers were defeated. Further examination of the common theme of dispossession and de-colonialization of the Japanese, German, and Italian colonial holdings in the post-war period provides new insights into the long process of decolonization. Although it may be true that none of the Japanese or Italian colonies adopted either Italian or Japanese as an official post-independence language, it is worth taking pause to note that this condition is rooted in their defeat. ${ }^{109}$ In places that had been heavily influenced by the Axis, it was the Allies, with the help of the United Nations, that drew the borders in the post-Second World War era and enforced their own ideals of democratization and linguistic authority on communities who came under their purview.

However, although Axis fascist imperialism was discredited, its ideas and ideologies persisted. The legacies of the anti-imperialist as well as anti-communist propaganda produced for and geared towards Muslims in areas under Axis control continued to percolate in the minds of revolutionaries throughout the Islamic world long after the war had ended. There were differences, of course, as the Nazis hoped to extend the Final Solution to the 700,000 Jews who lived in the Middle East and North Africa, whereas the Japanese found it difficult to come to terms with and promote anti-Semitism in East Asia. ${ }^{110}$ Recent works on the Nazi propaganda and campaigns in the Middle East and the Balkans aim to 'push the history of Nazism beyond its customary Eurocentric limits' and to examine the lasting impact of Nazi ideology on people beyond Germany. ${ }^{111}$ In a similar vein, Japan's Islamic policies provide new insights into the ways in which Japanese imperialists imagined the spatial and temporal boundaries of the Japanese imperial project to extend well beyond the Pacific.

After completing her PhD at Georgetown University in 2015, Kelly Hammond joined the Department of History at the University of Arkansas as an assistant professor of Modern East Asian History. She also serves as the book review editor for Twentieth-Century China.

109 Jaqueline Andall and Derek Duncan, 'Memories and legacies of Italian colonialism', in Jaqueline Andall and Derek Duncan, eds., Italian colonialism: legacy and memory, New York: Peter Lang, 2005, p. 17.

110 Herf, Nazi propaganda, prologue.

111 Ibid., p. 1. 